\title{
THE IMPACT OF TEACHER COMPETENCE, SCHOOL ENVIRONMENT AND SPIRITUAL ACTIVITIES ON THE LEARNING ACHIEVEMENT OF STUDENTS OF SMP BATIK SURAKARTA
}

\author{
Nurul Hidayati, Bambang Mursito, Kartika HendraTitisari \\ Program Pascasarjana Universitas Islam Batik Surakarta \\ Email:nurul.hidayati@gmail.com
}

\begin{abstract}
The problems presented relate to teacher competence, school environment and Spiritual Activities affect student achievement at SMP Batik Surakarta. This research method using research design is a survey research. This research was conducted at SMP Batik Surakarta in February 2020 - July 2020. The research reason was that learning achievement needs to be improved so that SMP Batik Surakarta students are able to obtain optimal learning achievement. The object of this study of Surakarta SMP Batik Surakarta, then of this research the population is totaling 303 students. The total population was 262 students from the total population, so in this study of $C$ class is 33 students. The analysis tool used is regression research, $t$ test, $F$ test and $R 2$ test. research result showed: there is influence of teacher competence, school environment and spiritual activities on the student achievement of Students in Surakarta Batik Junior High School partially and simultaneously
\end{abstract}

Keywords: Teacher Competence, School Environment, Spiritual Activities and Student Achievement

\section{PENDAHULUAN}

Suatu bangsa dapat dilihat kemampuan sumber daya manusia apabila dilihat dari segi pendidikan. Pendidikan salah satu bentuk pengembangan untuk menciptakan dan menghasilkan kemampuan yang dimiliki siswa dalam setiap belajar mengajar di dsekolah (Wahyuningsih, 2017). Pendidikan biasanya dilakukan di sekolah formal maupun non formal. Penerapan pendidikan di sekolah yang formal mempunyai struktur kepemimpinan masing-masing. Sekolah disini dapat diartikan sebagai sekolah yang komplek dan unik, terdiri dari beberapa manusia dalam rangka mencapai visi dan misi, sehingga memerlukan tingkat koordinasi yang tinggi. Pendidikan merupakan salah satu paling utama dalam pengembangan sumber daya manusia maka tenaga pendidik dan tenaga kependidikan tentunya memiliki tanggung jawab yang sangat besar dalam mengemban tugas ini. Sehingga standar mutu pendidik dan tenaga kependidikan perlu untuk ditingkatkan.

Kegiatan belajar mengajar di sekolah dibutuhkan kemampuan seorang pengajar/ pendidik. Pendidik/ guru memberikan peran dalam pengembangan kemampuan siswa dalam hal hasil belajar dalam bentuk prestasi belajar. Kemampuan guru memberikan kemajuan dunia pendidikan harus mempunyai visi dan misa dalam meningkatkan hasil yang diharapkan. Guru harus mengikuti perkembangan zaman karena dibutuhkan kemampuan yang memadai sehingga tidak tertinggal perkembangan dunia (Syaidah et.al, 2018).

Proses belajar mengajar di sekolah agar tercapai dengan baik maka dibutuhkan peran pendidik untuk mencapai tujuan tersebut. Faktor-faktor Pendidik harus dalam mencapai tujuan proses belajar mengajar harus memiliki kompetensi (kemampuan) 
yang harus dimiliki misalnya tingkat pendidikan yang tinggi akan memberikan andil dalam kemajuan dalam kegiatan belajar mengajar (KBM) sehingga akan meningkatkan kemampuan terdidik (siswa) (Umami dan Roesminingsih, 2014). Prestasi belajar merupakan hasil yang diperoleh terdidik dalam kegiatan belajar mengajar (KBM) dalam periode proses belajar mengajar di sekolah (Rosyid et.al (2019: 09).

Pendapat (Novauli, 2012) yang mempengaruhi kemampuan siswa (prestasi belajar) meliputi kesehatan, minat, bakat, intelegensi, emosi kelelahan. Begitu juga pendapat Rosyid et.al.,(2019: 10) kegiatan belajar mengajar (KBM) dipengaruhi oleh kemampuan terdidik, kompetensi guru, materi pengajaran, cara (metode mengajar) guru, sarana prasrana dan sistem evaluasi mengajar.

Pendapat Aziz (2018) menyatakan bahwa hasil hasil belajar (prestasi) merupakan hasil yang diperoleh terdididik dalam hubungan dengan faktor-faktor lain yang terkait dengan individu dengan luar individu.

Pendidik (guru) mempunyai kompetensi di kegiatan pendidikan sekolah dengan tujuan untuk mengembangkan ilmu, teknologi dengan berhubungan dengan guru dengan terdidik berjalan harmonis, bisa menyampaikan materi dengan jelas kepada terdidik (siswa), sehingga pendidikan diwajibkan memiliki penjiwaan (kepribadian) yang baik dan bertanggungjawab serta mempunyai kedisiplinan di kelas dan mampu mempunyai cara atau metode menerapkan metode belajar mengajar di sekolah sehingga siswa mampu menerima materi yang disampaikan guru di kelas serta menciptakan kondisi yang kondusif di kelas sehingga belajar mengajar terjamin kenyamanan dan bisa fokus terhadap materi yang disampaikan guru (Astriyani et.al, 2016).

Kegiatan belajar mengajar (KBM) berjalan dengan lancar dibutuhkan peran seorang guru/pendidik sehingga tujuan untuk meningkatkan hasil belajar (prestasi siswa) tercapai sehingga dibutuhkan motivasi/dorongan yang positif sehingga dapat mewujudkan tercapainya tujuan belajar mengajar di kelas. Motivasi/dorongan yang dibutuhkan guru untuk mencapai tujuan dibutuhkan kemampuan/kompetensi yang tinggi sehingga bisa menyakinkan kepada siswa untuk bisa memberikan semangat untuk belajar di kelas.

Peranan guru mencapai tujuan belajar mengajar di sekolah tercapai sehingga akan meningkatkan hasil belajar (prestasi siswa) sehingga dibutuhkan kemampuan/ kompetensi yang tinggi (Sintha et.al., 2016). Profesional/ kemampuan yang dimiliki tentang menguasai materi pelajaran, menguasai metode keilmuan pendidikan sehingga akan meningkatkan kualitas mengajar yang diberikan kepada terdidik berdasarkan kurikulumm yang berlaku di sekolah dengan tidak meninggalkan substansi keilmuan dari pemerintah. Pendidik merupakan seorang pengajar diharapkan mempunyai kemampuaan untuk paham kepribadian siswa dan perkembangan psikologis siswa Herlianto et.al, (2018).

Selain faktor lingkungan dan faktor guru kegiatan rohani juga memberikan dampak peningkatan hasil belajar (prestasi belajar). Ferdiansyah et.al (2019) mengadakan penelitian diperoleh hasil kegiatan rohani yang diikuti siswa memiliki dampak positif bagi prestasi siswa. Anwar (2015) mengemukakan kegiatan kerohanian Islam yang dapat dilakukan diantaranya: 1) berdoa dan membaca al-quran terlebih dahulu sebelum memulai pelajaran; 2) pembiasaan sholat dhuha pada jam istirahat pagi; 3) pada istirahat siang disesuaikan dengan jadwal sholat dzuhur, supaya warga sekolah baik guru dan siswa dapat melaksanakan sholat dzuhur berjamaah; 4) pada hari jumat diadakan sholat jumat berjamaah di masjid sekolahan atau di masjid yang berada di sekitar sekolahan; 5) setiap bulan ramadhan di adakan kegiatan yang berkenaan dengan keagamaan; 6) pada bulan ramadhan diadakan pengumpulan dan pembagian zakat fitrah di sekolah dan dibagikan dengan siswa; 7) pada hari raya idhul adha diadakan kegiatan latihan qurban. 
Berdasarkan wawancara pada tanggal 6 April 2020 dengan kepala sekolah di SMP Batik Surakarta. Kepala sekolah memberikan pendapat bahwa masih adanya kendala atau permasalahan yang dihadapi permasalahan di sekolah yaitu keterlambatan/tidak disiplin dalam hal masuk sekolah siswa dalam mengikuti proses pelajaran, sehingga menggangu dalam kegiatan belajar mengajar di kelas. Begitu juga adanya guru dalam menyususn RPP dalam tergolong sudah lama (digunakan materi lama) sehingga kurang dikatakan mewakili kondisi saat sekarang, untuk dibutuhkan guru yang mempunyai kemampuan dan kompeten dalam menyusun RPP sehingga tidak tertinggal dengan mata kuliah sekarang.

\section{Landasan Teori}

a. Kompetensi Guru

Seorang guru pasti memiliki kompetensi yang mumpuni dalam bidang pendidikan. Hal tersebut dapat terlihat pada saat guru melakukan kegiatan pembelajaran di kelas dengan siswanya. Guru memiliki peran penting dalam menentukan kualitas akademik siswanya. Kompetensi perlu dipahami terlebih dahulu guna meningkatkan kualitas dalam pembelajaran. "Kompetensi adalah kumpulan pengetahuan, perilaku, dan keterampilan yang harus dimiliki dosen untuk mencapai tujuan pembelajaran dan pendidikan" (Musfah, 2011: 27). "Kompetensi guru adalah seperangkat pengetahuan, keterampilan, dan perilaku yang harus dimiliki, dihayati, dan dikuasai oleh dosen dalam melaksanakan tugas keprofesionalan" (Estiningsih, 2014: $6)$.

Kompetensi guru merupakan perpaduan antara kemampuan personal, keilmuan, teknologi, sosial, dan spiritual yang secara kafah membentuk kompetensi standar profesi guru, yang mencakup penguasaan materi, pemahaman terhadap peserta didik, pembelajaran yang mendidik, pengembangan pribadi dan profesionalitas (Musfah, 2012: 27).

Guru diharapkan mampu menyajikan materi-materi dengan jelas dalam penyampaian mata pelajaran, salah satunya dengan mengembangkan kompetensi mengajar sehingga tujuan pembelajaran dapat dicapai dengan maksimal dan agar anggapan siswa yang keliru tersebut dapat ditepis. Guru berupaya untuk menampilkan rangsangan (stimulus) yang dapat diproses dengan berbagai indera. Hal tersebut sesuai dengan yang dikemukakan oleh Arsyad (2013: 9) semakin banyak alat indera yang digunakan untuk menerima dan mengolah informasi, semakin besar kemungkinan informasi tersebut dimengerti dan dapat dipertahankan dalam ingatan. Diharapkan guru lebih mudah dalam menyampaikan materi pelajaran, sehingga dapat membantu siswa dalam menerima dan menyerap dengan baik pesan-pesan dari materi yang disampaikan.

Guru dapat melakukan berbagai cara dalam mengajar, seperti memberi petunjuk, menyarankan, mendesak, membujuk, mendorong, membimbing, menunjuk, berbicara, memerintah, memberitahu, menceritakan, menyampaikan materi, mendemonstrasikan, melatih, menguji, meneliti, mengkritik, mengoreksi, mengarahkan, mengasah keterampilan, serta hal lain yang tidak menghambat pemahaman mahasiswa (Supriadie, 2012: 11). Guru yang berkompeten pada umumnya dilihat dari seberapa jauh guru menguasai materi dan menerapkan model pembelajaran yang tepat untuk materi yang dipelajari. Menurut Djamarah dan Zain (2013: 99) pendidik yang berkompeten adalah pendidik yang memiliki ketrampilan memberi penguatan, ketrampilan bertanya, ketrampilan mengadakan variasi, ketrampilan menjelaskan, dan keterampilan membuka dan menutup pelajaran. Sebagai salah satu 
tenaga pendidik profesional, dosen dituntut untuk menguasai beberapa kompetensi guna menunjang proses pembelajaran. "Seorang pendidik, guru harus mempunyai empat kompetensi dasar yaitu kompetensi pedagogik, kompetensi kepribadian, kompetensi sosial, dan kompetensi profesional, yaitu :

1) Kompetensi kepribadian merupakan kemampuan personal yang mencerminkan kepribadian yang mantap, stabil, dewasa, arif, dan berwibawa, menjadi teladan bagi peserta didik, dan berakhlak mulia.

2) Kompetensi pedagogik merupakan kemampuan yang berkenaan dengan pemahaman peserta didik dan pengelola pembelajaran yang mendidik dan dialogis.

3) Kompetensi profesional merupakan kemampuan yang berkenaan dengan penguasaan materi pembelajaran bidang studi secara luas dan mendalam yang mencakup penguasaan substansi isi materi kurikulum matapelajaran di sekolah dan substansi keilmuan yang menaungi materi kurikulum tersebut, serta menambah wawasan keilmuan sebagai dosen.

4) Kompetensi sosial berkenaan dengan kemampuan pendidik sebagai bagian dari masyarakat untuk berkomunikasi dan bergaul secara efektif dengan peserta didik, sesama pendidik, tenaga kependidikan, orangtua/wali peserta didik, dan masyarakat sekitar (Danim, 2010: 22).

\section{b. Lingkungan Sekolah}

Lingkungan secara umum diartikan sebagai kesatuan dengan semua benda, daya, keadaan, dan mahluk hidup, termasuk manusia dan perilakunya, yang mempengaruhi kelangsungan perikehidupan dan kesejahteraan manusia serta mahluk hidup lainya (Munib, 2011: 76). Sekolah merupakan lingkungan pendidikan yang secara sengaja dirancang dan dilaksanakan dengan aturan-aturan yang ketat seperti harus berjenjang dan berkesinambungan, sehingga disebut pendidikan formal dan sekolah adalah lembaga khusus, suatu wahana, suatu tempat untuk menyelenggarakan pendidikan, yang di dalamnya terdapat suatu proses belajar mengajar untuk mencapai tujuan pendidikan tertentu (Sabdulloh, 2010: 196).

Lingkungan sekolah adalah lingkungan dimana para siswa dibiasakan dengan nilai-nilai kegiatan pembelajaran sebagai bidang studi yang dapat meresap kedalam kesadaran hati nuraninya (Tu'u 2014: 11). Lingkungan sekolah merupakan lingkungan pendidikan utama yang kedua. Siswa-siswa, guru, administrator, konselor hidup bersama dan melaksanakan pendidikan secara teratur dan terencana dengan baik (Hasbullah, 2013: 36).

Lingkungan sekolah merupakan salah satu faktor yang turut mempengaruhi pertumbuhan dan perkembangan anak terutama untuk kecerdasannya. Lingkungan sekolah sangat berperan dalam meningkatkan pola pikir anak, karena kelengkapan sarana dan prasarana dalam belajar serta kondisi lingkungan yang baik sangat penting guna mendukung terciptanya lingkungan belajar yang menyenangkan (Dalyono, 2012: 131). Lingkungan sekolah yaitu keadaan sekolah tempat belajar yang turut mempengaruhi tingkat keberhasilan belajar. Keadaan gedung sekolahnya dan letaknya, serta alat-alat belajar yang juga ikut menentukan keberhasilan belajar siswa (Syah, 2010:152).

Menurut Hamalik (2009) lingkungan sekolah adalah sebagai tempat mengajar dan belajar. Sebagai suatu lembaga yang menyelenggarakan pengajaran dan kesempatan belajar harus memenuhi bermacam-macam persyaratan antara lain: murid, guru, program pendidikan, asrama, sarana dan fasilitas. Segala sesuatu telah diatur dan 
disusun menurut pola dan sistematika tertentu sehingga memungkinkan kegiatan belajar dan mengajar berlangsung dan terarah pada pembentukan dan pengembangan siswa.

Berdasarkan beberapa pengertian tersebut dapat disimpulkan bahwa lingkungan sekolah merupakan lingkungan tempat berlangsungnya proses pendidikan anak menjadi warga negara yang cerdas, terampil dan bertingkah laku baik. Lingkungan sekolah juga berperan penting dalam meningkatkan pola pikir siswanya karena di sekolah para siswa diajarkan bermacam-macam ilmu pengetahuan dan ketrampilan.

Lingkungan sekolah memegang peranan penting dalam perkembangan belajar peserta didik, lingkungan sekolah akan mempengaruhi motivasisetiap siswa dalam proses belajarnya. Lingkungan sekolah menjadi dua bagian yakni : 1) Lingkungan fisik sekolah seperti sarana dan prasarana belajar. 2) Lingkungan sosial menyangkut hubungan siswa dengan teman-temanya, guru-gurunya, staf sekolah yang lain, suasana sekolah dan pelaksanaan (Sukmadinata, 2015). Lingkungan sekolah turut mempengaruhi tingkat keberhasilan belajar siswa. Faktor sekolah yang mempengaruhi belajar mencakup metode mengajar, kurikulum, relasi guru dengan siswa, relasi siswa dengan siswa, disiplin sekolah, alat pelajaran, waktu sekolah dan keadaan gedung (Slameto, 2010). Faktor-faktor yang ada di dalam lingkungan sekolah sebagai berikut:

1) Guru

Guru adalah tenaga pendidik yang memberikan sejumlah ilmu pengetahuan kepada anak didik. Dengan ilmu dan keterampilan yang dimiliki, guru dapat menjadikan siswa menjadi individu yang cerdas dan disiplin.

2) Sarana dan prasarana

Prasarana dan sarana pembelajaran merupakan faktor yang berpengaruh terhadap motivasi belajar siswa. Keadaan gedung sekolah dan ruang kelas yang tertata rapi, ruang perpustakaan sekolah yang teratur, tersedianya fasilitas kelas dan laboratorium, tersedianya buku-buku pelajaran, media/alat bantu belajar merupakan komponen yang penting untuk mendukung kegiatan-kegiatan belajar.

3) Kondisi gedung

Diantaranya ventilasi udara yang baik, sinar matahari dapat masuk, penerangan lampu yang cukup, ruang kelas yang luas, kondisi gedung yang kokoh. Apabila suasana ruang gelap, ruangan sempit, tidak ada ventilasi dan gedung rusak akan menjadikan proses belajar yang kurang baik sehingga memungkunkan proses belajar menjadi terhambat. Ketersediaan prasarana dan sarana pembelajaran berdampak terhadap terciptanya iklim pembelajaran yang lebih kondusif, terjadinya kemudahan bagi siswa untuk mendapatkan informasi dan sumber belajar yang pada gilirannya dapat mendorong berkembangnya motivasiuntuk mencapai hasil belajar yang lebih baik (Tu'u, 2014).

\section{c. Kegiatan Rohani Islam}

Rohani Islam berasal dari dua kata yaitu Rohani dan Islam. Rohani artinya berkaitan dengan roh/rohaniah (Pusat Bahasa, 2005). Secara etimologis, "Islam" berasal dari bahasa Arab, diderivasikan dari "salima" yang berarti selamat sentosa. Dari kata ini dibentuk aslama yang berarti "memelihara dalam keadaan yang selamat sentosa", dan juga berarti "menyerahkan diri, tunduk, patuh, dan taat". Kata "aslama" itulah yang menjadi kata pokok dalam "Islam", mengandung segala arti yang ada dalam arti pokoknya (Syukur, 2010). 
Rohani Islam merupakan kegiatan Ekstrakurikuler yang dijalankan di luar jam pelajaran. Tujuannya untuk menunjang dan membantu memenuhi keberhasilan pembinaan Intrakurikuler, yang diantaranya yaitu meningkatkan suatu pengetahuan, ketrampilan, sikap, dan memperluas cara berfikir siswa yang kesemuanya itu dapat berpengaruh terhadap prestasi belajarnya (Yusuf, 2004).

Bedasarkan paparan di atas dapat disimpulkan bahwa rohani islam adalah kegiatan yang berkaitan dengan roh atau rohaniah yang biasanya dituangkan dalam bentuk kegiatan di luar jam pembelajaran (ektrakurikuler)guna meningkatkan pengetahuan, keterampilan, sikap, dan memperluar cara pikir yang dapat mempengaruhi prestasi belajar siswa.

\section{d. Prestasi Belajar Siswa}

1) Prestasi Belajar

Menurut Sudjana (2013) prestasi adalah keberhasilan murid dalam mempelajari materi pelajaran yang dinyatakan dengan angka yang diproleh siswa dari hasil tes dari materi- materi tertentu. Adapun menurut Nasrun (2014) prestasi belajar adalah penilaian pendidikan tentang perkembangan dan kemajuan murid yang berkenaan dengan penguasaan pelajaran yang disajikan kepada mereka serta nilai-nilai yang terdapat dalam kurikulum. Berdasarkan paparan di atas dapat dikatakan bahwa prestasi belajar yang diperoleh oleh siswa merupakan penguasaan pelajaran yang nantinya akan berpengaruh bagi capaian berikutnya.

Prestasi belajar dapat menunjukkan tingkat keberhasilan seseorang setelah melakukan proses belajar dalam melakukan perubahan dan perkembangannya. Hal ini disebabkan prestasi belajar merupakan hasil penilaian atas kemampuan, kecakapan dan keterampilan yang mampu meningkatkan pengalaman belajar sebab siswa dapat belajar dimanapun dan dalam kondisi apapun selama dirinya terhubung dengan internet tanpa harus mengikuti pembelajaran tatap muka (Syah, 2012).

Menurut Didin Mukodim, Ritandiyono dan Harumi Ratna Sita (2004: 112), prestasi belajar adalah hasil penilaian pendidik terhadap proses dan hasil belajar siswa yang menggambarkan penguasaan siswa atas materi pelajaran atau perilaku yang relatif menetap sebagai akibat adanya proses belajar yang dialami siswa dalam jangka waktu tertentu.

Dapat disimpulkan bahwa prestasi adalah perubahan penilaian yang diperoleh peserta didik setalah melakukan proses belajar mengajar yang bertujuan untuk meningkatkan pengetahuan, keterampilan, dan sikap.

2) Faktor yang Mempengaruhi Prestasi Belajar

Secara garis besar faktor-faktor yang mempengaruhi prestasi belajar menurut Slameto (2010) terdiri dari dua golongan, yaitu faktor intern dan faktor ekstern. Faktor intern yaitu faktor yang berasal dari dari dalam diri siswa, seperti keadaan jasmani, psikologis, intelektual, minat dan motivasi. Sedangkan faktor ekstern adalah faktor yang berasal dari luar siswa, seperti keluarga, sekolah,masyarakat, sarana dan fasilitas belajar. Kedua faktor ini tidak dapat dipisahkan karena satu dengan yang lain adalah saling berkaitan dan dapat mempengaruhi hasil belajar siswa.

Adapun menurut Syah (2010) terdapat tiga faktor yang mempengaruhi prestasi belajar siswa, yaitu faktor interen, eksteren, dan pendekatan belajar. Faktor intern yaitu faktor yang berasal dari dalam siswa itu sendiri dengan meliputi dua aspek yaitu aspek fisiologis (bersifat jasmaniah) dan aspek psikologi (bersifat 
rohaniah). Aspek fisiologis siswa terdapat pada kondisi umum jasmani dan tonus (tangan otot) yang menandai tingkat kebugaran organ-organ tubuh dan sendisendinya, dapat mempengaruhi semangat dan intensitas siswa dalam mengikuti pelajaran. Kondisi organ tubuh yang lemah, apalagi jika disertai dengan pusing kepala misalnya, dapat menurunkan kualitas ranah cipta (kognitif) sehingga materi yang dipelajarinya pun kurang atau tidak terbekas.

Faktor eksternal siswa terdiri dari dua macam, yakni faktor lingungan sosial dan non sosial. Yang termasuk dalam lingkungan sosial sekolah adalah guru dan teman-teman sekelas. Para guru yang selalu menunjukkan sikap dan perilaku yang simpatik dan memperhatikan suri tauladan yang baik dan rajin dalam hal belajar, dapat menjadi daya dorong yang positif bagi kegiatan belajar siswa. Selanjutnya yang termasuk dalam lingkungan sosial siswa adalah masyarakat dan tetangga juga teman-teman sepermainan. Kondisi masyarakat di lingkungan kumuh yang serba kekurangan dan anak-anak jalanan, misalnya akan sangat mempengaruhi aktifitas belajar siswa. Paling tidak siswa itu akan menemukan kesulitan ketika memerlukan teman belajar atau berdiskusi atau sekedar meminjam alat- alat belajar tertentu yang kebtulan belum dimilikinya. Lingkungan sosial yang lebih banyak mempengaruhi kegiatan belajar siswa adalah orang tua dan keluarga siswa itu sendiri

Selain faktor internal dan eksternal, faktor pendekatan belajar juga berpengaruh terhadap taraf keberhasilan proses pembelajaran. Seorang siswa yang terbiasa mengaplikasikan pendekatan belajaran deep misalnya, mungkin sekali berpeluang untuk meraih prestasi belajar yang bermutu dari pada siswa yang menggunakan pendekatan belajar surface atau reproduktif. pernyataan ini menggambarkan bahwa semakin tinggi kemampuan siswa dan kualitas pengajaran, maka semakin tinggi pula hasil belajar siswa.

\section{METODE PENELITIAN}

Desain penelitian merupakan penelitian survey. Penelitian ini dilakukan di SMP Batik Surakarta bulan Februari 2020 - Juli 2020. Alasan penelitian adalah prestasi belajar perlu ditingkatkan agar siswa SMP Batik Surakarta mampu memperoleh prestasi belajar optimal. Siswa kelas 8 sebagai objek penelitian. Jumlah populasi sekitar 303 siswa sengan jumlah 33 siswa di kelas C. Alat analisis meliputi regresi berganda (uji t,uji F dan uji $\mathrm{R}^{2}$ ).

\section{HASIL ANALISIS DAN PEMBAHASAN Hasil Analisis}

a. Perhitungan alat analisis (Regresi Linier Berganda)

Analisis ini digunakan untuk menentukan pengaruh variabel Kompetensi Guru $\left(\mathrm{X}_{1}\right)$, Kompetensi guru $\left(\mathrm{X}_{2}\right)$, Lingkungan Sekolah $\left(\mathrm{X}_{3}\right)$, dan dengan Prestasi Belajar siswa (Y).

Tabel 1 Rekapitulasi Regresi Linier Berganda

\begin{tabular}{lcccc}
\hline \multicolumn{1}{c}{ Variabel } & $\beta$ & $\mathrm{t}$ & tabel & Signifikan \\
\hline (Constant) & 42,286 & & & \\
Kompetensi Guru & 0,423 & 2,056 & 2,045 & 0,049 \\
Lingkungan Sekolah & 0,168 & 2,112 & 2,045 & 0,043 \\
Kegiatan Rohani & 0,677 & 2,605 & 2,045 & 0,014 \\
\hline $\mathrm{F} \quad=31,971$ & Sig. $=0,00$ & & & \\
\hline
\end{tabular}




$\mathrm{R}^{2} \quad=0,768$

Penyajian uraian di atas:

$\mathrm{Y}=42,286+0,423 \mathrm{X}_{1}+0,168 \mathrm{X}_{2}+0,677 \mathrm{X}_{3}$

Penilaian hasil:

1) a=Konstanta sekitar 42,286 atau signifikan, meskipun Kompetensi Guru, Lingkungan Sekolah, dan Kegiatan Rohani tetap / tidak berubah maka Prestasi Belajar siswa naik.

2) $b_{1}=0,423$, coefisien regresi Kompetensi Guru sekitar 0,423 atau artinya dengan adanya peningkatan Kompetensi Guru sehingga naik Prestasi Belajar siswa sekitar 0,423.

3) $\mathrm{b}_{2}=0,168$, coefisien regresi Lingkungan Sekolah sekitar 0,168 atau artinya Kegiatan Rohani naik akan naik Prestasi Belajar siswa sekitar 0,168.

4) $b_{3}=0,677$, coefisien regresi Kegiatan Rohani sekitar 0,677 atau artinya Kegiatan Rohani naik akan naik Prestasi Belajar siswa sekitar 0,677.

b. Uji t

Perhitungan uji t Variabel $\mathrm{X}_{1}$ (Kompetensi Guru) berkaitan (pengaruh) secara signifikan dengan dengan Y (Prestasi Belajar siswa) pada SMP Batik Surakarta, dibuktikan hasil dari thitung $=2,056>$ ttabel $=2,045$, untuk itu kompetensi guru secara signifikan berkaitan (pengaruh) dengan Prestasi Belajar siswa.

Variabel $\mathrm{X}_{2}$ (Lingkungan Sekolah) berkaitan (pengaruh) secara signifikan dengan dengan Y (Prestasi Belajar siswa) pada SMP Batik Surakarta, dibuktikan hasil dari thitung= 2,112>ttabel $=2,045$, untuk itu Lingkungan Sekolah secara signifikan berkaitan (pengaruh) dengan Prestasi Belajar siswa.

Variabel $\mathrm{X}_{3}($ Kegiatan Rohani) berkaitan (pengaruh) secara signifikan dengan Y (Prestasi Belajar siswa) pada SMP Batik Surakarta, dibuktikan hasil dari thitung= 2,605>ttabel= 2,045, untuk itu Kompetensi guru secara signifikan berkaitan (pengaruh) dengan Prestasi Belajar siswa.

c. Uji F

Uji F sekitar 31,971>2,934, artinya variabel X (Kompetensi Guru, Lingkungan Sekolah dan Kegiatan Rohani) berkaitan (pengaruh) dengan prestasi belajar siswa, dalam kondisi fit and good.

d. Uji $\mathrm{R}^{2}$ (coefisien determinasi)

Nilai Coefisien determinasi $\left(\mathrm{R}^{2}\right)$ sekitar 0,768, artinya variabel X (Kompetensi Guru , Lingkungan Sekolah dan Kegiatan Rohani) menjelaskan variasi prestasi belajar siswa di SMP Batik Surakarta sekitar 76,8\% dan 23,2\% dari variabel lainnya.

\section{Pembahasan}

\section{Hubungan Kompetensi Guru dengan Prestasi Belajar}

Perhitungan analisis menyatakan: Kompetensi Guru berkaitan (pengaruh) signifikan dengan prestasi belajar siswa. Ini menunjukkan bahwa Kompetensi Guru berkaitan (pengaruh) signifikan dengan prestasi belajar siswa. Aga Dwi Sintha, Harini, Sunarto (2016) menunjukkan hasil bahwa kompetensi guru dengan prestasi belajar siswa. Hasil tersebut menunjukkan bahwa kompetensi guru berkaitan (pengaruh) positif dengan prestasi belajar siswa, artinya bahwa dengan guru memiliki kemampuan atau kompetensi 
semakin tinggi akan mempengaruhi peningkatan kemampuan siswa dalam bidang pendidikan di proses belajar mengajar di sekolah, sehingga kemampuan atau kompetensi guru sangat dibutuhkan siswa dalam mengembangkan kemampuan yang dimilikinya. Keberhasilan penyelenggaraan pembelajaran sangat ditentukan oleh kesiapan guru dalam mempersiapkan peserta didik melalui kegiatan pembelajaran. Apabila guru memiliki kesiapan yang kurang, maka guru tersebut tidak dapat memberikan performa yang optimal dan siswa akan cenderung memberikan respon yang negative dengan pembelajaran yang diberikan oleh guru tersebut. Oleh karena itu kompetensi guru dinilai sangat berkaitan (pengaruh) dengan prestasi belajar.

\section{Hubungan Lingkungan Sekolah Dengan Prestasi Belajar}

Perhitungan analisis menyatakan: Lingkungan Sekolah berkaitan (pengaruh) signifikan dengan Prestasi Belajar siswa. Ini menunjukkan bahwa Lingkungan Sekolah berkaitan (pengaruh) signifikan dengan Prestasi Belajar siswa, artinya semakin Lingkungan Sekolah yang baik antar karyawan dan atasan akan meningkatkan Prestasi Belajar siswa. Ini ada dukungan dari Sri Wahyuningsih (2017) yang menyatakan bahwa Lingkungan Sekolah mempunyai kaitan (pengaruh) signifikan dengan prestasi belajar siswa. Kondisi lingkungan sekolah pada dasarnya mempunyai andil dalam perkembangan suasana baik di kelas maupun di luar kelas. Kondisi yang nyaman dan aman di lingkungan akan membuat siswa merasakan adanya keamanan dan kenyamanan dari kebisingan dan suasana gaduh sehingga proses belajar mengajar akan tercapai dengan baik, begitu juga guru akan memberikan pelajaran yang baik dan fokus dengan materi yang disampaikan. Seyogyanya kondisi lingkungan kelas maupun luar kelas perlu dijaga agar tercapai berjalannya kegiatan belajar mengajar.

\section{Hubungan Kegiatan Rohani Dengan Prestasi Belajar}

Perhitungan analisis menyatakan: Kegiatan Rohani berkaitan (pengaruh) signifikan dengan Prestasi Belajar siswa. Ini menunjukkan bahwa Kompetensi guru berkaitan (pengaruh) signifikan dengan Prestasi Belajar siswa. Kegiatan rohani merupakan kegiatan yang dilakukan di luar jam pelajaran dengan tujuan mengasah kompetesi, sikap, dan karekter guna menunjang hasil belajar siswa. Berdasarkan penelitian yang dilakukan oleh M Anwar (2015) menunjukkan hasil bahwa Kegiatan rohani dengan prestasi belajar siswa. Kegiatan rohani yang diberikan sekolah di luar pelajaran formil atau kegiatan ekstrakuler akan memberikan manfaat kepada siswa untuk memperdalam pelajaran agama dengan tujuan bisa diterapkan dalam pergaulan di sekolah, rumah atau lingkungan rumah. Kegiatan rohani ini akan berdampak besar perilaku siswa-siswi dalam menerapkan etika pergaulan berdasarkan agama sehingga tidak menyimpang dari aturan agama, setidaknya bisa menjaga diri dan menjaga akhlak berdasarkan agama.

\section{KESIMPULAN}

1) Variabel $X_{1}$ (Kompetensi Guru) berkaitan (pengaruh) secara signifikan dengan dengan $Y$ (Prestasi Belajar siswa) pada SMP Batik Surakarta, dibuktikan hasil dari thitung= 2,056>ttabel $=2,045$, untuk itu kompetensi guru secara signifikan berkaitan (pengaruh) dengan Prestasi Belajar siswa.

2) Variabel $X_{2}$ (Lingkungan Sekolah) berkaitan (pengaruh) secara signifikan dengan dengan Y (Prestasi Belajar siswa) pada SMP Batik Surakarta, dibuktikan hasil dari thitung= 2,112>ttabel $=2,045$, untuk itu Lingkungan Sekolah secara signifikan berkaitan (pengaruh) dengan Prestasi Belajar siswa. 
3) Variabel $X_{3}($ Kegiatan Rohani) berkaitan (pengaruh) secara signifikan dengan $Y$ (Prestasi Belajar siswa) pada SMP Batik Surakarta, dibuktikan hasil dari thitung= 2,605 $>$ ttabel= 2,045, untuk itu Kompetensi guru secara signifikan berkaitan (pengaruh) dengan Prestasi Belajar siswa.

\section{DAFTAR PUSTAKA}

Arikunto, S. 2010. Prosedur Penelitian suatu Pendekatan Praktik. Jakarta : Rineka Cipta.

Astriyani, Gimin, Hendripides, 2016, Pengaruh Kemampuan Mengajar Guru Dan Fasilitas Belajar Dengan Hasil Belajar Siswa Di SMP Negeri 7 Bintan Desa Numbing Kecamatan Bintan Pesisir Kabupaten Bintan

Aziz, A. 2018. Kontribusi Lingkungan Belajar dan Proses Pembelajaran Dengan Prestasi Belajar Siswa di Sekolah. Jurnal Tarbiyah. Vol 25. No. 2.

Danim, 2010, Pengantar Kependidikan, Bandung : Alfabeta.

Djamarah \& Zain. 2013. Strategi Belajar Mengajar. Jakarta: Rineka Cipta.

Ferdiansyah. Akmal, Retno Triwoelandari dan , Syarifah Gustiawati , 2019, Ekstrakurikuler Rohis Dalam Pengaruhnya Dengan Motivasi Belajar Siswa, SAP (Susunan Artikel Pendidikan), Vol. 4 No.2.

Herlianto. Jajang Ikbal, Suwatno \& Herlina, 2018, Pengaruh Kemampuan Profesional Guru Dan Motivasi Belajar Siswa Dengan Prestasi Belajar Siswa Pada Mata Pelajaran Kearsipan SMK Administrasi Perkantoran Di SMK Negeri 1 Ciamis, Manajerial, Vol. 3 No.4, Hal - 70.

Kunandar. 2008. Guru Profesional_Implementasi Kurikulum_tingkat satuan pendidikan dan Sukses dalam Sertifikasi Guru. Jakarta: PT. Raja Grafindo Persada

Musfah, Jejen. 2011. Peningkatan Kemampuan Guru : Melalui Pelatihan dan Sumber Belajar Teori dan Praktik. Jakarta : Prenada Media Group

Sabdulloh, Uyoh. 2010. Pedagogik Ilmu Mendidik. Bandung: Alfabeta.

Sarmila Banerjee, Namita Das and Atasi Mohanty, 2015, Impact of Teacher Competence and Teaching Effectiveness on Students' Achievement in Life Science Subject at the Upper Primary Stage Antea

Syah, Muhibbin. 2010. Psikologi Belajar. Jakarta: Rajagrafindo Persada 